\title{
PERAN PARTISIPASI ANGGARAN DALAM PENINGKATAN KINERJA ORGANISASI
}

\author{
Danang K. ${ }^{1}$, Aprih Santoso ${ }^{2}$ \\ Prodi MM Universitas Semarang \\ aprihsantoso@usm,ac.id
}

\begin{abstract}
ABSTRAK
Tujuan penelitian untuk menguji pengaruh karakteristik sistem informasi dan desentralisasi terhadap kinerja organisasi serta menguji partisipasi anggaran dalam memoderasi pengaruh karakteristik sistem informasi akuntansi dan desentralisasi terhadap kinerja organisasi pada PoliteknikIlmuPelayaran Semarang. Populasi penelitian ini adalah Pegawai Bagian Keuangan Politeknik Ilmu Pelayaran Semarang yang berjumlah 65 orang dimana jumlah tersebut diambil seluruhnya sebagai sampel atau dikatakan sebagai penelitian populasi (census). Pengujian instrumen dalam penelitian menggunakan : uji validitas, uji reliabilitas, uji normalitas, uji heteroskedastisitas, uji multikolinearitas, koefisien determinasi, uji model (uji F) dan uji hipotesis (uji t). Metode analisis data menggunakan regresi linear berganda. Hasil penelitian menunjukkan adanya pengaruh antara karakteristik informasi akuntansi dan desentralisasi terhadap kinerja organisasi sehingga hipotesis pertama dan kedua terbukti atau dapat diterima. Partisipasi anggaran mampu memoderasi pengaruh karakteristik informasi akuntansi dan desentralisasi terhadap kinerja organisasi sehingga hipotesis ketiga dan keempat terbukti atau dapat diterima.
\end{abstract}

Kata kunci : partisipasi anggaran, informasi akuntansi, desentralisasi, kinerja organisasi

\begin{abstract}
The research objective was to examine the effect of the characteristics of information systems and decentralization on organizational performance and to examine budgetary participation in moderating the effect of the characteristics of accounting information systems and decentralization on organizational performance at the Semarang Telecommunications Polytechnic. The population of this research is 65 employees of the Finance Department of Semarang Shipping Science Polytechnic where the total number is taken as a sample or said to be a population study (census). Testing instruments in this study used: validity test, reliability test, normality test, heteroscedasticity test, multicollinearity test, determination coefficient, model test ( $F$ test) and hypothesis testing ( $t$ test). The data analysis method used multiple linear regression. The results showed that there was an influence between the characteristics of accounting information and decentralization on organizational performance so that the first and second hypotheses were proven or accepted. Budget participation is able to moderate the effect of the characteristics of accounting information and decentralization on organizational performance so that the third and fourth hypotheses are proven or acceptable.
\end{abstract}


Keywords : budget participation, accounting information, decentralization, organizational performance.

\section{PENDAHULUAN}

Tujuan utama kebanyakan organisasi tersebut adalah untuk memperoleh keuntungan atau laba maksimum, dan untuk mencapai tujuan organisasi maka organisasi harus memiliki kinerja yang tinggi (Muzaki et al, 2017). .Perencanaan sistem informasi merupakan bagian dari sistem pengendalian organisasi yang perlu mendapatkan perhatian, sehingga bisa diharapkan memberikan kontribusi positif didalam mendukung keberhasilan kinerja organisasi. Salah satu fungsi dari sistem informasi adalah menyediakan informasi penting untuk membantu manajer mengendalikan aktivitasnya sehingga diharapkan dapat membantu perusahaan ke arah pencapaian tujuan dengan sukses. Informasi yang dihasilkan suatu sistem informasi merupakan sumber daya bagi organisasi, dimana informasi tersebut dapat mendukung manajemen dalam pengambilan keputusan yang berdampak pada kinerja organisasi. Kajian tentang strategi sistem informasi dalam setiap pengambilan keputusan yang telah ditetapkan dan dijalankan dengan menggunakan informasi yang tepat, relevan dan benar akan menunjang keberhasilan dalam tercapainya tujuan perusahaan (Susanti et al. 2020). Kinerja organisasi yang selama ini hanya dinilai dari sisi keberhasilan capaian finansial, sekarang menjadi bergeser bahwa tidak hanya masalah untung besar saja yang dianggap memiliki kinerja bagus (Santoso et al, 2018).

Salah satu faktor yang mempengaruhi kinerja organisasi adalah sistem informasi akuntansi. Sistem informasi akuntansi (accounting information systems), menyediakan informasi dan transaksi keuangan (Waluyo \& Budiarsi, 2016). Kualitas informasi akuntansi yang disajikan dalam bentuk laporan dapat digunakan sebagai dasar pembuatan keputusan, maka manajemen keuangan dituntut untuk dapat menyajikan informasi akuntansi yang berkualitas atau karakteristik, yaitu: a) Relevan (relevant), b) Dapat dipercaya (realible), c) Lengkap (complete), d) Tepat waktu (timely),e) Mudah dipahami (understandable) dan f) Dapat diuji kebenarannya, (diferivikasi) (Krismiaji, 2010). Penelitian Yudista et al. (2016); Sayyida (2013); Fitriani (2013); Nuraini \& Rosyati (2012), Senduk et al. (2017) tentang pengaruh karakteristik informasi akuntansi terhadap kinerja organisasi. Hasil penelitiannya adalah karakteristik informasi akuntansi berpengaruh terhadap kinerja organisasi. Penelitian lain tentang kinerja organisasi yang hasilnya tidak 
konsisten dengan penelitian di atas adalah tentng karakteristik informasi akuntansi yang bersifat understandable dan verifiable tidak berpengaruh terhadap kinerja manajerial pada Palang Merah Indonesia (PMI) Provinsi Jawa Tengah (Cahyaningrum \& Suprapti, 2016).

Faktor lain yang mempengaruhi kinerja organisasi adalah desentralisasi. Menurut Dwirandra (2007) desentralisasi merupakan pendelegasian wewenang dan tanggungjawab kepada para manajer. Tingkat pendelegasian itu sendiri menunjukkan sampai seberapa jauh manajemen yang lebih tinggi mengijinkan manajemen yang lebih rendah untuk membuat kebijakan secara independen (Ratnawati \& Setyaningsih, 2011). Pendelegasian yang diberikan kepada manajemen yang lebih rendah (subordinate) dalam otoritas pembuatankeputusan (decision making) akan diikuti pula tanggung jawab terhadap aktivitas yang mereka lakukan. Otoritasadalah memberikan hak untuk menentukan penugasan, sedangkan tanggung jawab adalah kewajiban untuk mencapai tugas yang telah ditetapkan (Ratnawati \& Setyaningsih, 2011).

Desentralisasi dalam bentuk pendistribusian otoritas pada manajemen yang lebih rendah diperlukan karena semakin kompleksnya kondisi administratif, tugas, dan tanggung jawab. Pendelegasian wewenang maka akan membantu meringankan beban manajemen yang lebih tinggi. Ratnawati \& Setyaningsih (2011) menunjukkan bahwa tingkat desentralisasi yang tinggi merupakanbentuk yang tepat untuk menghadapi peningkatan ketidakpastian sehingga menunjang pencapaian kinerjamanajerial yang lebih baik. Penelitian sebelumnya mengenai pengaruh desentralisasi terhadap kinerja organisasi pernah dilakukan Afrida (2013); Tarjono \& Nugraha (2015); Meiliza (2018); Senduk et al. (2017) yang menemukan bahwa desentralisasi berpengaruh positif dan signifikan terhadap kinerja organisasi. Namun penelitian tersebut berlawanan dengan Ratnawati \& Setyaningsih (2011) justru menunjukan desentralisasi tidak berpengaruh terhadap kinerja organisasi.

Apabila pengaruh suatu variabel terhadap variabel lain masih ambigu, maka peneliti berikutnya dapat memasukkan variabel moderasi, dimana variabel modeerasi tersebut harus pernah diuji sebelumnya sebagai variabel bebas terhadap variabel terikat (Sekaran, 2006). Setyarini \& Susty (2014); Sukmantari \& Wirasedana (2015); Nuraini \& Rosyati (2012); Yudista et al. (2016), yang menemukan bahwa partisipasi anggaran berpengaruh positif dan signifikan terhadap kinerja organisasi. Terkait dengan pernyataan Sekaran (2006) dan hasil penelitian Setyarini \& Susty (2014); Sukmantari \& Wirasedana 
(2015); Nuraini \& Rosyati (2012); Yudista et al. (2016) serta hasil penelitian terdahulu yang berbeda-beda atas hasil penelitian pengaruh karakteristik informasi akuntansi keuangan dan desentralisasi terhadap kinerja organisasi di atas maka peneliti memasukkan variabel baru sebagai variabel moderasi yaitu partisipasi anggaran karena partisipasi anggaran adalah suatu proses yang melibatkan individu-individu secara langsung di dalamnya dan mempunyai pengaruh terhadap penyusunan tujuan anggaran yang prestasinya akan dinilai dan kemungkinan akan dihargai atas dasar pencapaian tujuan anggaran mereka. Sebuah anggaran yang baik adalah anggaran yang dapat memenuhi semua kebutuhan dalam organisasi sehingga dapat mmpengaruhi kinerja organisasi. Karakteristik informasi akuntansi keuangan yang baik dan desentralisasi yang baik merupakan pendelegasian wewenang dan tanggungjawab yang tepat serta didukung oleh partisipasi anggaran yang baik akan dapat meningkatkan kinerja organisasi.

Beranjak uraian di atas, penelitian ini akan mengintegrasikan pengaruh karakteristik sistem informasi akuntansi dan desentralisasi terhadap kinerja organisasi dengan moderasi partisipasi anggaran yang hasilnya belum konsisten. Adapun yang menjadi obyek penelitian adalah Politeknik Ilmu Pelayaran Semarang yang merupakan salah satu Lembaga Pendidikan Maritim Negeri dibawah naungan Kementerian Perhubungan dan satu - satunya yang berada di Jawa Tengah, yang berlokasi di Jalan Singosari 2a Semarang dengan tugas pokok membina dan mencetak lulusan perwira perwira kapal niaga, baik kapal - kapal milik Negara maupun kapal - kapal swasta. Dengan berjalannya waktu dan bertambahnya usia, pada saat ini Politeknik Ilmu Pelayaran Semarang sedang mengalami masalah yakni kurang maksimalnya kinerja organisasi, Hal ini dapat diakibatkan karena pegawai tentang karakteristik informasi akuntansi masih kurang seperti: pengetahuan, kemampuan dan keterampilan serta sikap pegawai yang kebanyakan tidak mau mengembangkan diri. Untuk desentralisasi, bentuk pendistribusian otoritas pada manajemen yang lebih rendah mengenai administratif, tugas, dan tanggung jawab terkadang tidak jelas sehingga output pekerjaan kurang maksimal. Untuk partisipasi anggaran permasalahan yang sering terjadi adalah : 1) kurangnya partisipasi staff dalam penyusunan anggaran sehingga hasil yang diharapkan tidak maksimal, 2) pengalokasian anggaran yang diterima tidak sesuai perencanaan, 3) kurangnya perhatian pimpinan dalam mendorong middle management karena tidak ada penghargaan dn saksi yang tegas dari pimpinan dan 4) kurang maksimalnya pelimpahan wewenang yang diberikan kepada 
middle management sehingga mengurangi gerak untuk lebih kreatif, inovatif dan aktif dalam pemilihan dan pemimdahan staff sesuai dengan kemampuan. pelaksanaan kegiatankegiatan pada Politeknik Ilmu Pelayaran Semarang sebagaian besar belum dapat dilaksanakan tepat waktunya sehingga mengakibatkan kinerja organisasi kurang maksimal. Kinerja organisasi belum maksimal juga diakibatkan sering terjadi pelanggaran kerja pegawai. Adapun tujuan penelitian untuk menguji pengaruh karakteristik sistem informasi dan desentralisasi terhadap kinerja organisasi serta menguji partisipasi anggaran dalam memoderasi pengaruh karakteristik sistem informasi akuntansi dan desentralisasi terhadap kinerja organisasi pada PoliteknikIlmuPelayaran Semarang

\section{TELAAH PUSTAKA DAN PENGEMBANGAN HIPOTESIS}

\section{Teori Kinerja Organisasi}

Persaingan dalam dunia bisnis semakin ketat, mengharuskan sebuah organisasi melakukan transformasi untuk dapat bertahan, bersaing dan menghadapi perubahan (Hartono \& Anshori. 2019). Rivai (2011) mengungkapkan kinerja organisasi adalah sebagai hasil akhir dari keseluruhan kegiatan yang dilakukan oleh perusahaan yang disesuaikan dengan kriteria-kriteria yang telah ditetapkan. Kinerja organisasi atau kinerja perusahaan merupakan indikator tingkatan prestasi yang dapat dicapai danmencerminkan keberhasilan manajer/pengusaha. Jadi kinerja organisasi merupakan hasil yang diinginkan organisasi dari perilaku orang-orang didalamnya.

Sistem penilaian prestasi kinerja yang baik sangat tergantung pada persiapan yang benar-benar baik dan memenuhi syarat-syarat sebagai berikut (Fitriani, 2013): 1) praktis, 2) kejelasan standar, 3) kriteria yang objektif, yaitu : a) reliability, b) relevance, c) sensitivity, d) practicality. 4) Penggunaan prosedur baku perusahaan, seperti sifat tenang, menerapkan tarif dasar untuk panggilan telepon, dan berpedomon aturan perusahaan, 5) cara telepon yang menyenangkan, berbicara secara jelas dan berlaku sopan santun, 6) ketelitian menyampaikan telepon, penempatan operator yang teliti dalam meneruskan permintaan nomor telepon dengan akurat.

Kinerja merupakan suatu proses yang digunakan oleh pimpinan untuk menentukan apakah seorang karyawan melakukan pekerjaan sesuai dengan tugas dan tanggung jawabnya atau tidak, sehingga langkah-langkah yang digunakan untuk mewakili 
kinerja dipilih berdasarkan keadaan organisasi yang sedang diamati (Puryantini et al. 2017). Kinerja organisasi ini diukur dengan mempergunakan indikator Mahonay et. al, (1963), terdiri : 1) perencanaan, 2) investigasi, 3) koordinasi, 4) evaluasi, 5) supervisi, 6) staffing, 7) negosiasi. serta 8) representasi.

\section{Teori Partisipasi Anggaran}

Pada dasarnya proses penyusunan anggaran adalah merupakan kegiatan yang penting dan melibatkan berbagai pihak, seperti manajer dan bawahan yang sama-sama memegang peranan penting dalam mempersiapkan dan mengevaluasi penyusunan anggaran tersebut serta tujuan dari anggaran itu sendiri dan anggaran juga dapat digunakan sebagai tolak ukur kinerja manajer (Febrianti \& Riharjo, 2013). Anggaran disusun manajemen dalam jangka waktu satu tahun untuk membawa perusahaan ke kondisi tertentu yang diperhitungkan. Dengan anggaran manajemen mengarahkan jalannya kondisi perusahaan. Anggaran mempunyai bebrapa fungsi di antaranya adalah : (1) Fungsi Perencanaan; (2) Fungsi Koordinasi; (3) Fungsi Komunikasi. (4) Fungsi Motivasi; (5) Fungsi Pengendalian dan Motivasi. (6) Fungsi Pendidikan. Partisipasi anggaran merupakan keterlibatan antara manajer atas dengan bawah untuk menentukan proses penggunaan sumber daya pada aktivitas danoperasi perusahaan (Eker, 2007).

\section{Teori Desentralisasi}

Desentralisasi merupakan pendelegasian wewenang dan tanggung jawab kepada para manajer. Tingkatpendelegasian itu sendiri menunjukkan sampai seberapa jauh manajemen yang lebih tinggi mengizinkanmanajemen yang lebih rendah untuk membuat kebijakan secara independen (Ratnawati \& Setyaningsih, 2011). Pendelegasian yang diberikan kepada manajemen yang lebih rendah (subordinate) dalam otoritas pembuatankeputusan (decision making) akan diikuti pula tanggung jawab terhadap aktivitas yang mereka lakukan. Otoritasadalah memberikan hak untuk menentukan penugasan, sedangkan tanggung jawab adalah kewajiban untukmencapai tugas yang telah ditetapkan (Ratnawati \& Setyaningsih, 2011).

Sodikin (2015), desentralisasi adalah pendelegasian wewenang kepada manajer yang arasnya lebih rendah. Desentralisasi dalam bentuk pendistribusian otoritas pada manajemen yang lebih rendah diperlukankarena semakin kompleksnya kondisi 
administratif, tugas, dan tanggung jawab. Dengan pendelegasianwewenang maka akan membantu meringankan beban manajemen yang lebih tinggi. Ratnawati \& Setyaningsih (2011) menegaskan bahwa desentralisasi dibutuhkan sebagai respons terhadap lingkungan yang tidak dapat diramalkan. Ratnawati \& Setyaningsih (2011), menunjukkan bahwa tingkat desentralisasi yang tinggi merupakan bentuk yang tepat untukmenghadapi peningkatan ketidakpastian sehingga menunjang pencapaian kinerja manajerial yang lebih baik. Ratnawati \& Setyaningsih (2011) menyatakan bahwa tingkat desentralisasi juga mempengaruhi bagaimana informasi seperti informasi akuntansi manajemen, evaluasi kinerjadikumpulkan, diproses dan dikomunikasikan dalam organisasi.

\section{Teori Karakteristik Informasi Akuntansi}

Informasi dibutuhkan oleh suatu organisasi atau perusahaan guna mengetahui keadaan yang terjadi. Informasi selalu dikaitkan dengan data. Data merupakan suatu fakta, persepsi atau apapun yang akan diolah atau disimpan. Informasi diperlukan oleh manajer untuk mengurangi ketidakpastian dalam pengambilan keputusan. Romney et al (2015) menambahkan bahwa informasi adalah data yang telah dikelola dan diproses untuk memberikan arti dan memperbaiki proses pengambilan keputusan. Sebagaimana perannya, pengguna membuat keputusan yang lebih baik sebagai kuantitas dan kualitas dari peningkatan informasi. Terdapat empat karakteristik informasi akuntansi menurut Ikatan Akuntan Indonesia (2015) sebagai syarat-syarat informasi laporan keuangan yang bermanfaat :1) understandable (dapat dipahami), 2) relevant (relevan), 3) reliable (keandalan), 4) Comparability (dapat dibandingkan)

\section{Hubungan karakteristik informasi akuntansi terhadap kinerja organisasi}

Robbins (2006) menyatakan dalam melaksanakan tugasnya manajer membutuhkan informasi dari berbagai sumber yang sifatnya luas. Manajer membutuhkan informasi yang memiliki karakteristik informasi akuntansi bersifat relevant, dapat dipercaya (reliable), lengkap (complete), tepat waktu (timely), mudah dipahami (Understandable) serta dapat diuji kebenarannya (verifiable) (Krismiaji, 2010). Penelitian mengenai karakteristik informasi akuntansi pernah dilakukan Penelitian Yudista et al. (2016); Sayyida (2013); Fitriani (2013); Nuraini \& Rosyati (2012), Senduk et al. (2017) dimana hasil penelitian karakteristik informasi akuntansi berpengaruh yang positif dan 
signifikan terhadap kinerja organisasi. Dari uraian di atas maka hipotesis pertama dari penelitian adalah :

$\mathrm{H}_{1}$ : Karakteristik informasi akuntansi berpengaruh positif dan signifikan terhadap kinerja organisasi.

\section{Hubungan desentralisasi terhadap kinerja organisasi}

Desentralisasi dalam bentuk pendistribusian otoritas pada manajemen yang lebih rendah diperlukan karena semakin kompleksnya kondisi administratif, tugas, dan tanggung jawab. Dengan pendelegasianwewenang maka akan membantu meringankan beban manajemen yang lebih tinggi. Ratnawati \& Setyaningsih (2011) menunjukkan tingkat desentralisasi yang tinggi merupakan bentuk yang tepat untuk menghadapi peningkatan ketidakpastian sehingga menunjang pencapaian kinerja manajerial yang lebih baik.

Penelitian sebelumnya mengenai pengaruh desentralisasi terhadap kinerja manajerial pernah dilakukan oleh Afrida (2013); Tarjono \& Nugraha (2015); Meiliza (2018); Senduk et al. (2017) yang menghasilkan desentralisasi berpengaruh positif dan signifikan terhadap kinerja organisasi. Dari uraian diatas maka hipotesis kedua dari penelitian ini adalah :

$\mathrm{H}_{2}$ : Desentralisasi berpengaruh positif dan signifikan terhadap kinerja organisasi

\section{Partisipasi anggaran memoderasi pengaruh karakteristik sistem informasi akuntansi terhadap kinerja organisasi.}

Dengan karakteristik informasi akuntansi yang baik dan didukung oleh partisipasi anggaran yang baik akan dapat meningkatkan kinerja organisasi. Partisipasi anggaran adalah suatu proses yang melibatkan individu-individu secara langsung di dalamnya dan mempunyai pengaruh terhadap penyusunan tujuan anggaran yang prestasinya akan dinilai dan kemungkinan akan dihargai atas dasar pencapaian tujuan anggaran mereka. Sebuah anggaran yang baik adalah anggaran yang dapat memenuhi semua kebutuhan dalam organisasi sehingga dapat mmpengaruhi kinerja organisasi.

Dari uraian di atas maka hipotesis ketiga dari penelitian ini adalah :

$\mathrm{H}_{3}$ : Partisipasi anggaran memoderasi pengaruh karakteristik sistem informasi akuntansi terhadap kinerja organisasi 


\section{Partisipasi anggaran memoderasi pengaruh desentralisasi terhadap kinerja organisasi}

Desentralisasi yang merupakan pendelegasian wewenang dan tanggung jawab yang tepat serta didukung oleh partisipasi anggaran yang baik akan dapat meningkatkan kinerja organisasi. Partisipasi tersebut menunjukkan adanya interaksi antara para karyawan dengan atasannya, dan karyawan melakukan aktivitas yang diperlukan dari awal penyusunan anggaran, negosiasi, penetapan anggaran akhir dan revisi anggaran yang diperlukan.Sebuah anggaran yang baik adalah anggaran yang dapat memenuhi semua kebutuhan dalam organisasi sehingga dapat mempengaruhi kinerja organisasi. Dari uraian di atas maka hipotesis keempat dari penelitian ini adalah :

\section{$\mathrm{H}_{4}$ : Partisipasi anggaran memoderasi pengaruh desentralisasi terhadap kinerja organisasi}

\section{Kerangka Pemikiran Teoritis}

Manajer membutuhkan informasi dari berbagai sumber yang sifatnya luas. Karena itu manajer membutuhkan informasi yang memiliki karakteristik informasi akuntansi yang informasinya yang memiliki cakupan yang luas dan lengkap (completeness) dan desentralisasi yang merupakan pendelegasian wewenang dan tanggung jawab kepada para manajer. Dengan karakteristik informasi akuntansi yang baik dan desentralisasi yang merupakan pendelegasian wewenang dan tanggung jawab yang tepat serta didukung oleh partisipasi anggaran yang baik akan dapat meningkatkan kinerja organisasi. 
Berdasarkan uraian di atas, maka kerangka pemikiran teoritis dalam penelitian ini sebagai berikut :

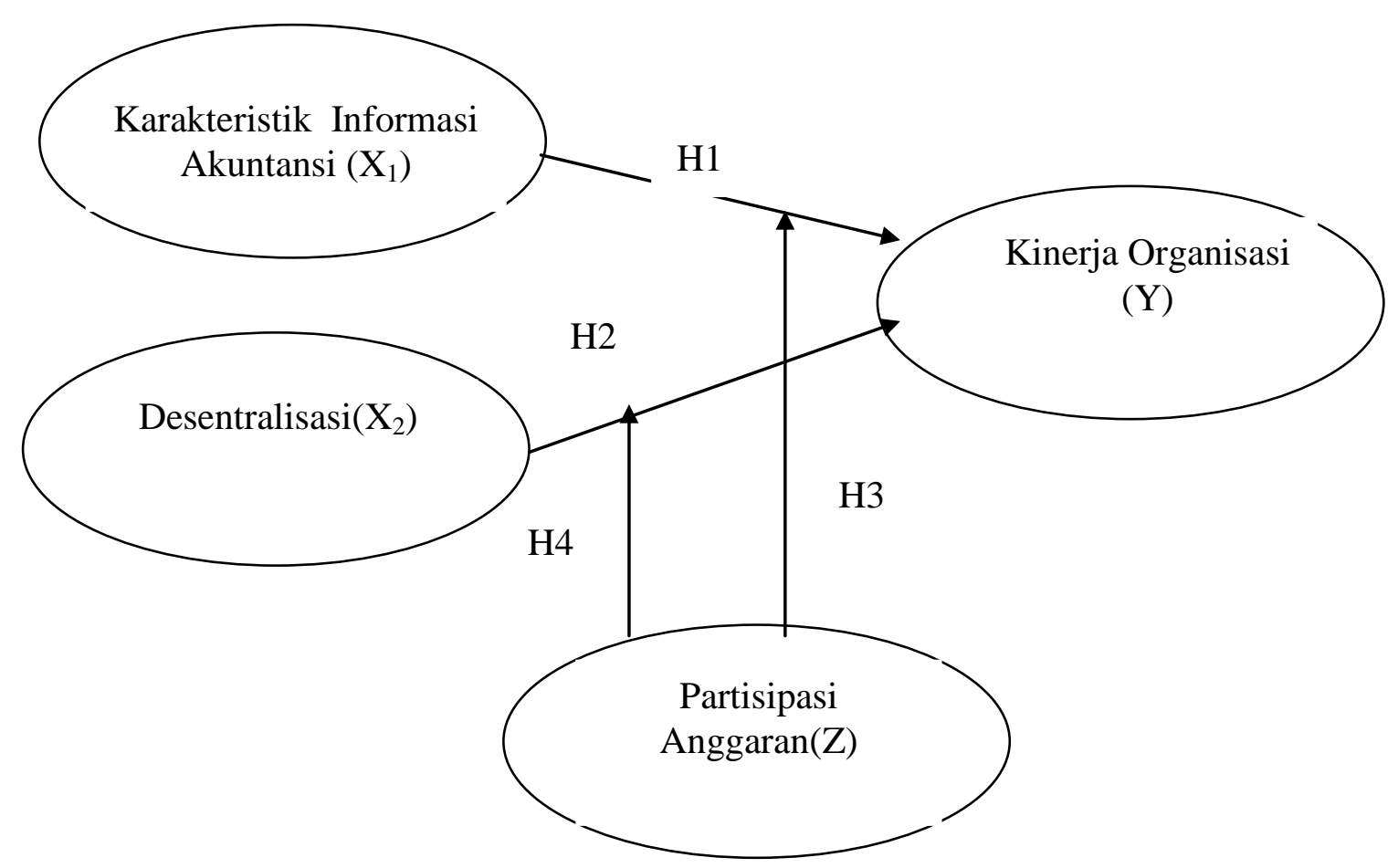

Gambar 1. Model Penelitian

\section{METODE}

\section{Populasi dan Sampel}

Populasi penelitian ini adalah Pegawai Bagian Keuangan Politeknik Ilmu Pelayaran Semarang yang berjumlah 65 orang dimana jumlah tersebut diambil seluruhnya sebagai sampel atau dikatakan sebagai penelitian populasi (census).

\section{Variabel Penelitian}

Variabel terikat (dependent) dalam penelitian ini adalah kinerja organisasi (Y) sedangkan variabel bebas (independent) : karakteristik informasi akuntansi $\left(\mathrm{X}_{1}\right)$, desentralisasi $\left(\mathrm{X}_{2}\right)$ dan variabel moderasi adalah partisipasi anggaran $(\mathrm{Z})$. 
Tabel 1. Definisi Operasional Variabel

\begin{tabular}{|c|c|c|}
\hline Variabel & Definisi Operasional & Indikator \\
\hline $\begin{array}{l}\text { 1. Karakteristik } \\
\text { Informasi } \\
\text { Akuntansi(X1) } \\
\text { meliputi : }\end{array}$ & $\begin{array}{l}\text { Sistem informasi akuntansi merupakan } \\
\text { suatu komponen atau subsistem dari } \\
\text { suatu organisasi karena mempunyai } \\
\text { tanggung jawab dalam menyiapkan } \\
\text { informasi keuangan guna membantu } \\
\text { manajemen dalam pembuatan keputusan } \\
\text { Meliputi : (Krismiaji, 2010) }\end{array}$ & $\begin{array}{l}\text { 1) Menambah pengetahuan bagi para pembuat } \\
\text { keputusan, } \\
\text { 2) Mengurangi ketidakpastian, } \\
\text { 3) Menaikkan kemampuan untuk } \\
\text { memprediksi, } \\
\text { 4) Menegaskan / membenarkan ekspektasi } \\
\text { dimasa lalu }\end{array}$ \\
\hline a. Relevant & $\begin{array}{l}\text { Relevant adalah menambah pengetahuan } \\
\text { atau nilai bagi para pembuat keputusan, } \\
\text { dengan cara mengurangi ketidakpastian, } \\
\text { menaikkan kemampuan untuk } \\
\text { memprediksi, atau menegaskan / } \\
\text { membenarkan ekspektasi semula }\end{array}$ & \\
\hline b. Reliable & $\begin{array}{l}\text { Realible adalah bebas dari kesalahan } \\
\text { atau bias dan secara akurat } \\
\text { menggambarkan kejadian atau aktivitas } \\
\text { organisasi }\end{array}$ & $\begin{array}{l}\text { 1) Bebas dari kesalahan dan bias } \\
\text { 2) Secara akurat menjelaskan kejadian atau } \\
\text { aktivitas organisasi }\end{array}$ \\
\hline c.Complete & $\begin{array}{l}\text { Complete adalah tidak menghilangkan } \\
\text { data penting yang dibutuhkan oleh para } \\
\text { pemakai }\end{array}$ & $\begin{array}{l}\text { 1) Informasi tersebut tidak meninggalkan } \\
\text { aspek-aspek penting } \\
\text { 2) Melatarbelakangi suatu kejadian }\end{array}$ \\
\hline d. Timely & $\begin{array}{l}\text { Timily adalah disajikan pada saat yang } \\
\text { tepat untuk mempengaruhi proses } \\
\text { pembuatan keputusan }\end{array}$ & $\begin{array}{l}\text { 1) Informasi tepat waktu, } \\
\text { 2) informasi ada bila dibutuhkan }\end{array}$ \\
\hline e.Understandable & $\begin{array}{l}\text { Understandable adalah disajikan dalam } \\
\text { format yang mudah dimengerti }\end{array}$ & $\begin{array}{l}\text { 1) Informasi disajikan dalam format yang } \\
\text { berguna. } \\
\text { 2) Informasi dapat dimengerti }\end{array}$ \\
\hline f. Verifiable & $\begin{array}{l}\text { Verifiableadalah memungkinkan dua } \\
\text { orang yang kompeten untuk } \\
\text { menghasilkan informasi yang sama } \\
\text { secara independen(Krismiaji, 2010) }\end{array}$ & $\begin{array}{l}\text { 1) Informasi dapat diuji kebenarannya } \\
\text { 2) Menghasilkan informasi yang sama }\end{array}$ \\
\hline $\begin{array}{l}\text { 2. Desentralisasi } \\
\left(\mathrm{X}_{2}\right)\end{array}$ & $\begin{array}{l}\text { Desentralisasi merupakan pendelegasian } \\
\text { wewenang dan tanggung jawab kepada } \\
\text { para manajer (Dwirandra, 2007) }\end{array}$ & $\begin{array}{l}\text { 1. Delegasi } \\
\text { 2. Wewenang } \\
\text { 3. Tanggungjawab }\end{array}$ \\
\hline
\end{tabular}




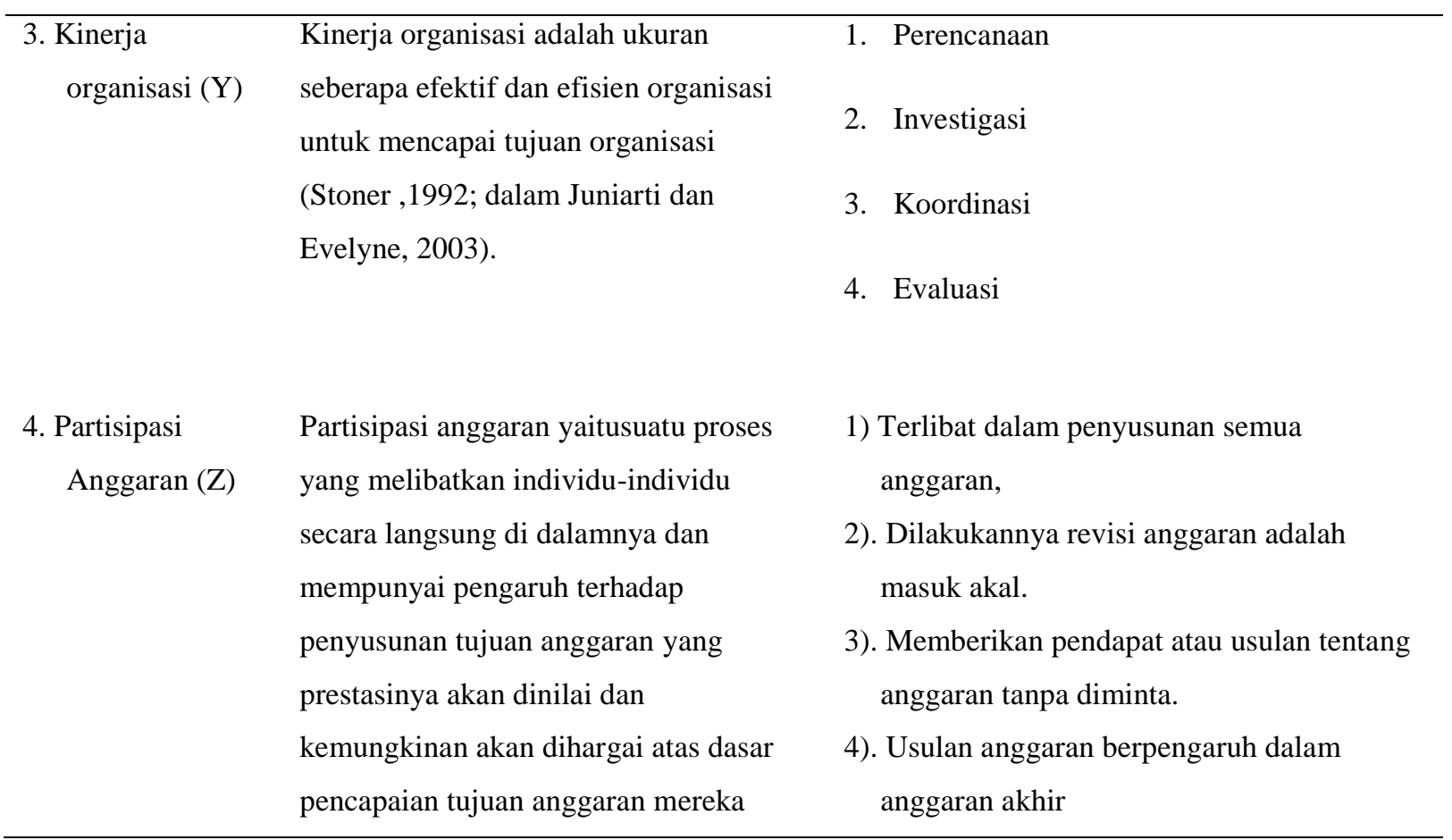

\section{Pengujian Instrumen Penelitian}

Pengujian instrumen dalam penelitian ini menggunakan dua alat instrumen:Uji Validitas, Uji Reliabilitas, Uji Normalitas, Uji Heteroskedastisitas, Uji Multikolinearitas, Koefisien determinasi, Uji Model (Uji F) dan Uji Hipotesis (uji t).

\section{Metode Analisis Data}

\section{Regresi Linear Berganda}

Persamaan antara variabel independen dan variabel dependen dengan rumus sebagai berikut :

$$
Y=\alpha+\beta_{1} X_{1}+\beta_{2} X_{2}+e
$$

\section{Persamaan Regresi Linear Bergandaa Dengan Variabel Moderating}

Metode Multiple Regression Analysis (MRA) dilakukan dengan menambahkan variabel perkalian antara variabel bebas dengan variabel moderatingnya, sehingga persamaan umumnya:

$$
Y=\alpha+\beta_{3} X_{1}+\beta_{4} X_{2}+\beta_{5} Z+\beta_{6} X_{1} \cdot Z+\beta_{7} X_{2} \cdot Z+e
$$

Keterangan : 


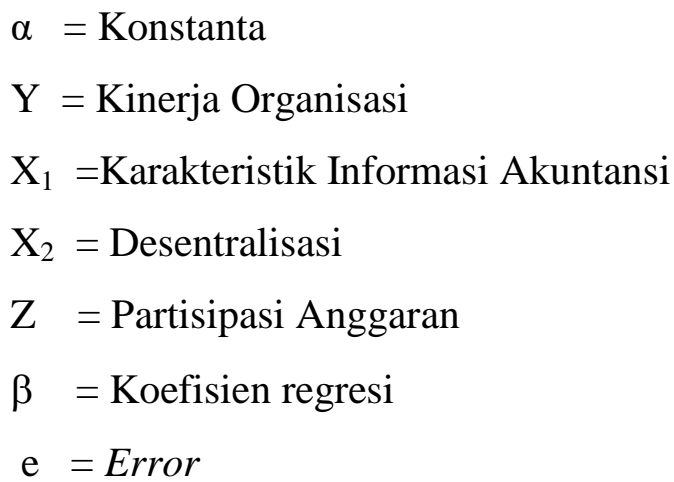

\section{HASIL DAN PEMBAHASAN}

\section{Karakteristik Informasi Akuntansi}

Secara keseluruhan variabel karakteristik informasi akuntansi terdiri dari 14 pertanyaan.

Tabel 2. Variabel Karakteristik Informasi Akuntansi

\begin{tabular}{llc}
\hline \multicolumn{1}{c}{ Indikator } & Mean & Kriteria \\
\hline Menambah pengetahuan bagi para pembuat & 3.57 & Cukup Baik \\
keputusan(X1.1) & 3.77 & Baik \\
Mengurangi ketidakpastian(X1.2) & 3.38 & Cukup Baik \\
Menaikkan kemampuan untuk memprediksi(X1.3) & 3.38 & Cukup Baik \\
$\begin{array}{l}\text { Menegaskan / membenarkan ekspektasi dimasa } \\
\text { lalu(X1.4) }\end{array}$ & 3.60 & Cukup Baik \\
$\begin{array}{l}\text { Bebas dari kesalahan dan bias(X1.5) } \\
\text { Secara akurat menjelaskan kejadian atau aktivitas }\end{array}$ & 3.65 & Cukup Baik \\
organisasi(X1.6) & & \\
Informasi tersebut tidak meninggalkan aspek-aspek & 4.15 & Baik \\
$\begin{array}{l}\text { penting (X1.7) } \\
\text { Melatarbelakangi suatu kejadian(X1.8) }\end{array}$ & 3.62 & Baik \\
Informasi tepat waktu(X1.9) & 4.17 & Cukup Baik \\
Informasi ada bila dibutuhkan(X1.10) & 4.25 & Baik \\
Informasi disajikan dalam format yang & 4.18 & Baik \\
berguna(X1.11) & 3.60 & Baik \\
Informasi dapat dimengerti(X1.12) & 4.02 & Cukup Baik \\
$\begin{array}{l}\text { Informasi dapat diuji kebenarannya (X1.13) } \\
\text { Menghasilkan informasi yang sama(X1.14) }\end{array}$ & & \\
\hline
\end{tabular}


Berdasarkan tabel 2 diketahui secara keseluruhan nilai mean karakteristik informasi akuntansi antara 3,38 - 4,25 yang berarti responden menyatakan karakteristik informasi akuntansi pada Politeknik Ilmu Pelayaran Semarang adalah baik.

\section{Desentralisasi}

Secara keseluruhan variabel desentralisasi terdiri dari 3 pertanyaan.

Tabel 3. Variabel Desentralisasi

\begin{tabular}{lcc}
\hline \multicolumn{1}{c}{ Indikator } & Mean & Kriteria \\
\hline Delegasi (X2.1) & 4.23 & Baik \\
Wewenang (X2.2) & 4.31 & Baik \\
Tanggungjawab (X2.3) & 3.83 & Baik \\
\hline
\end{tabular}

Berdasarkan tabel 3 diketahui bahwa secara keseluruhan nilai mean desentralisasi antara 3,83 - 4,31 yang berarti responden menyatakan desentralisasi pegawai pada Politeknik Ilmu Pelayaran Semarangadalah baik.

\section{Partisipasi Anggaran}

Secara keseluruhan variabel partisipasi anggaran terdiri dari 4 pertanyaan.

Tabel 4 Variabel Partisipasi Anggaran

\begin{tabular}{llc}
\hline \multicolumn{1}{c}{ Indikator } & Mean & Kriteria \\
\hline Terlibat dalam penyusunan semua anggaran & 4.15 & Tinggi \\
$\begin{array}{l}\text { (Z1.1) } \\
\text { Dilakukannya revisi anggaran adalah masuk } \\
\text { akal (Z1.2) }\end{array}$ & 3.83 & Tinggi \\
$\begin{array}{l}\text { Memberikan pendapat atau usulan tentang } \\
\text { anggaran tanpa diminta (Z1.3) }\end{array}$ & 4.12 & Tinggi \\
$\begin{array}{l}\text { Usulan anggaran berpengaruh dalam anggaran } \\
\text { akhir (Z1.4) }\end{array}$ & 4.18 & Tinggi \\
\hline
\end{tabular}

Berdasarkan tabel 4 diketahui bahwa secara keseluruhan nilai meanpartisipasi anggaranantara 3,83 - 4,18 yang berarti responden menyatakan partisipasi anggaran pegawai pada Politeknik Ilmu Pelayaran Semarang tinggi. 


\section{Kinerja Organisasi}

Secara keseluruhan variabel kinerja organisasi terdiri dari 4 pertanyaan.

Tabel 5. Variabel Kinerja Organisasi

\begin{tabular}{lcc}
\hline \multicolumn{1}{c}{ Indikator } & Mean & Kriteria \\
\hline Perencanaan (Y1.1) & 4.42 & Baik \\
Investigasi (Y1.2) & 4.29 & Baik \\
Koordinasi (Y1.3) & 4.09 & Baik \\
Evaluasi (Y1.4) & 3.57 & Cukup Baik \\
\hline
\end{tabular}

Berdasarkan tabel 5 diketahui bahwa secara keseluruhan nilai mean kinerja organisasi antara 3,57 - 4,42 yang berarti responden menyatakan kinerja organisasiPoliteknik Ilmu Pelayaran Semarang baik.

\section{Uji Validitas}

Adapun hasil pengujian validitas menunjukkan bahwa semua indikator dalam penelitian ini dinyatakan valid karena $r$ hitung $>r$ tabel, sebagaimana ditunjukkan dalam tabel 6. Oleh karena itu, layak untuk diujikan ke pengujian selanjutnya.

\section{Tabel 6. Hasil Uji Validitas}

\begin{tabular}{|c|c|c|c|c|}
\hline Variabel & Indikator & $\mathrm{r}$ hitung & $\mathrm{r}$ tabel & Ket. \\
\hline Karakteristik & Menambah pengetahuan bagi para pembuat & 0,730 & 0,244 & Valid \\
\hline Informasi Akuntansi & keputusan(X1.1) & & & \\
\hline \multirow[t]{13}{*}{$(\mathrm{X} 1)$} & Mengurangi ketidakpastian(X1.2) & 0,736 & 0,244 & Valid \\
\hline & Menaikkan kemampuan untuk memprediksi (X1.3) & 0,654 & 0,244 & Valid \\
\hline & Menegaskan / membenarkan ekspektasi dimasa & 0,872 & 0,244 & Valid \\
\hline & lalu(X1.4) & & & \\
\hline & Bebas dari kesalahan dan bias(X1.5) & 0,532 & 0,244 & Valid \\
\hline & Secara akurat menjelaskan kejadian atau aktivitas & 0,744 & 0,244 & Valid \\
\hline & organisasi(X1.6) & & & \\
\hline & Informasi tersebut tidak meninggalkan aspek-aspek & 0,530 & 0,244 & Valid \\
\hline & penting $(\mathrm{X} 1.7)$ & & & \\
\hline & Melatarbelakangi suatu kejadian(X1.8) & 0,680 & 0,244 & Valid \\
\hline & Informasi tepat waktu(X1.9) & 0,782 & 0,244 & Valid \\
\hline & Informasi ada bila dibutuhkan (X1.10) & 0,691 & 0,244 & Valid \\
\hline & Informasi disajikan dalam format yang & 0,494 & 0,244 & Valid \\
\hline
\end{tabular}




\begin{tabular}{|c|c|c|c|c|}
\hline & berguna $(\mathrm{X} 1.11)$ & & & \\
\hline & Informasi dapat dimengerti(X1.12) & 0,706 & 0,244 & Valid \\
\hline & Informasi dapat diuji kebenarannya (X1.13) & 0,582 & 0,244 & Valid \\
\hline & Menghasilkan informasi yang sama(X1.14) & 0,379 & 0,244 & Valid \\
\hline \multirow[t]{3}{*}{ Desentralisasi (X2) } & Delegasi (X2.1) & 0,954 & 0,244 & Valid \\
\hline & Wewenang (X2.2) & 0,924 & 0,244 & Valid \\
\hline & Tanggungjawab (X2.3) & 0,643 & 0,244 & Valid \\
\hline Partisipasi & Terlibat dalam penyusunan semua anggaran (Z1.1) & 0,404 & 0,244 & Valid \\
\hline \multirow[t]{3}{*}{ Anggaran $(Z)$} & $\begin{array}{l}\text { Dilakukannya revisi anggaran adalah masuk akal } \\
\text { (Z1.2) }\end{array}$ & 0,759 & 0,244 & Valid \\
\hline & $\begin{array}{l}\text { Memberikan pendapat atau usulan tentang anggaran } \\
\text { tanpa diminta (Z1.3) }\end{array}$ & 0,908 & 0,244 & Valid \\
\hline & $\begin{array}{l}\text { Usulan anggaran berpengaruh dalam anggaran akhir } \\
\text { (Z1.4) }\end{array}$ & 0,856 & 0,244 & Valid \\
\hline \multirow{4}{*}{$\begin{array}{l}\text { Kinerja Organisasi } \\
\text { (Y) }\end{array}$} & Perencanaan (Y1.1) & 0,815 & 0,244 & Valid \\
\hline & Investigasi (Y1.2) & 0,755 & 0,244 & Valid \\
\hline & Koordinasi (Y1.3) & 0,512 & 0,244 & Valid \\
\hline & Evaluasi (Y1.4) & 0,871 & 0,244 & Valid \\
\hline
\end{tabular}

\section{Hasil Uji Reliabilitas}

Tabel 7. Hasil Pengujian Reliabilitas

\begin{tabular}{lccc}
\hline \multicolumn{1}{c}{ Variabel } & Alpha Cronbach & $\begin{array}{c}\text { Angka Standar } \\
\text { Reliabel }\end{array}$ & Kriteria \\
\hline Karakteristik Informasi Akuntansi $\left(\mathrm{X}_{1}\right)$ & 0,844 & 0,7 & Reliabel \\
Desentralisasi $\left(\mathrm{X}_{2}\right)$ & 0,808 & 0,7 & Reliabel \\
Partisipasi Anggaran $(\mathrm{Z})$ & 0,717 & 0,7 & Reliabel \\
Kinerja Organisasi(Y) & 0,719 & 0,7 & Reliabel \\
\hline
\end{tabular}

Pada tabel di atas variabel karakteristik informasi akuntansi $\left(\mathrm{X}_{1}\right)$, desentralisasi $\left(\mathrm{X}_{2}\right)$, partisipasi anggaran $(\mathrm{Z})$ dan kinerja organisasi $(\mathrm{Y})$ dikatakan reliabel karena Alpha Cronbach $>0,7$ sehingga layak untuk diujikan ke pengujian selanjutnya 


\section{Uji Normalitas}

Tabel 8. Hasil Pengujian Normalitas Persamaan I

One-Sample Kolmogorov-Smirnov Test

\begin{tabular}{llr}
\hline & & $\begin{array}{c}\text { Unstandardized } \\
\text { Residual }\end{array}$ \\
\hline $\mathrm{N}$ & Mean & 65 \\
Normal Parameters & & .0000000 \\
& Std. Deviation & 1.73859779 \\
Most Extreme Differences & Absolute & .114 \\
& Positive & .092 \\
& Negative & -.114 \\
Kolmogorov-Smirnov Z & & .921 \\
Asymp. Sig. (2-tailed) & & .365 \\
\hline a. Test distribution is Normal. & &
\end{tabular}

Berdasarkan tabel 8 diketahui bahwa uji normalitas persamaan I pengaruh karakteristik informasi akuntansi dan desentralisasi terhadap kinerja organisasi tingkat signifikan 0,365 > 0,05 maka model regresi terdistribusi normal, oleh sebab itu dapat dilakukan pengujian selanjutnya.

Tabel 9. Hasil Pengujian Normalitas Persamaan II

One-Sample Kolmogorov-Smirnov Test

\begin{tabular}{llr}
\hline & & \multicolumn{2}{c}{$\begin{array}{c}\text { Unstandardized } \\
\text { Residual }\end{array}$} \\
\hline $\mathrm{N}$ & Mean & 65 \\
Normal Parameters $^{\mathrm{a}}$ & Std. Deviation & .0000000 \\
& Absolute & .98355929 \\
Most Extreme Differences & Positive & .162 \\
& Negative & .127 \\
Kolmogorov-Smirnov Z & & -.162 \\
Asymp. Sig. (2-tailed) & & 1.306 \\
\hline
\end{tabular}




\begin{tabular}{llr}
\multicolumn{2}{c}{ One-Sample Kolmogorov-Smirnov Test } \\
\hline & & $\begin{array}{c}\text { Unstandardized } \\
\text { Residual }\end{array}$ \\
\hline $\mathrm{N}$ & Mean & 65 \\
Normal Parameters ${ }^{\mathrm{a}}$ & Std. Deviation & .0000000 \\
Most Extreme Differences & Absolute & .98355929 \\
& Positive & .162 \\
Kolmogorov-Smirnov Z & Negative & .127 \\
Asymp. Sig. (2-tailed) & & -.162 \\
\hline a. Test distribution is Normal. & & 1.306 \\
\end{tabular}

Berdasarkan tabel 9 diketahui uji normalitas persamaan II yaitu pengaruh karakteristik informasi akuntansi dan desentralisasi terhadap kinerja organisasidengan mediasi partisipasi anggaran, tingkat signifikan 0,066>0,05 maka model regresi terdistribusi normal maka dapat dilakukan pengujian selanjutnya.

\section{Uji Heteroskedastisitas}

Tabel 10. Hasil Pengujian Heterkedastisitas Persamaan I

\begin{tabular}{|c|c|c|c|c|c|c|}
\hline \multicolumn{7}{|c|}{ Coefficients $^{\mathrm{a}}$} \\
\hline & & \multirow{2}{*}{\multicolumn{2}{|c|}{ Unstandardized Coefficients }} & \multirow{2}{*}{$\begin{array}{l}\text { Standardized } \\
\text { Coefficients }\end{array}$} & \multirow[b]{3}{*}{$\mathrm{t}$} & \multirow[b]{3}{*}{ Sig. } \\
\hline & & & & & & \\
\hline \multicolumn{2}{|c|}{ Model } & B & Std. Error & Beta & & \\
\hline \multirow[t]{3}{*}{1} & (Constant) & 2.473 & 1.007 & & 2.456 & .117 \\
\hline & $\begin{array}{l}\text { Karakteristik Informasi } \\
\text { Akuntansi }\end{array}$ & -.021 & .016 & -.171 & -1.321 & .191 \\
\hline & Desentralisasi & .006 & .063 & .013 & .100 & .921 \\
\hline
\end{tabular}

Berdasarkan tabel 10 diketahui bahwa hasil nilai signifikansi $(0,191$ dan 0,921) > 0,05 maka tidak terjadi heteroskedastisitas. 
Pengaruh karakteristik informasi akuntansi dan desentralisasi terhadap kinerja organisasi dengan mediasi partisipasi anggaran.

Tabel 11. Hasil Pengujian Heterkedastisitas Persamaan II

\begin{tabular}{|c|c|c|c|c|c|c|}
\hline \multicolumn{7}{|c|}{ Coefficients $^{\mathrm{a}}$} \\
\hline & & \multirow{2}{*}{\multicolumn{2}{|c|}{ Unstandardized Coefficients }} & \multirow{3}{*}{$\begin{array}{c}\text { Standardized } \\
\text { Coefficients } \\
\text { Beta }\end{array}$} & \multirow[b]{3}{*}{$\mathrm{t}$} & \multirow[b]{3}{*}{ Sig. } \\
\hline & & & & & & \\
\hline \multicolumn{2}{|c|}{ Model } & B & Std. Error & & & \\
\hline \multirow[t]{8}{*}{1} & (Constant) & 4.654 & 2.643 & & 1.761 & .083 \\
\hline & Karakteristik Informasi & -.089 & .076 & -.965 & -1.174 & .245 \\
\hline & Akuntansi & & & & & \\
\hline & Desentralisasi & -.104 & .183 & -.287 & -.566 & .573 \\
\hline & Partisipasi Anggaran & .102 & .161 & .373 & .633 & .529 \\
\hline & Interaksi KIA dengan & .000 & .005 & .110 & .071 & .943 \\
\hline & Parisipasi Anggaran & .000 & & & & \\
\hline & $\begin{array}{l}\text { Interaksi Desentralisasi } \\
\text { dengan Parisipasi Anggaran }\end{array}$ & .000 & .012 & .021 & .027 & .979 \\
\hline
\end{tabular}

a. Dependent Variable: abs2

Berdasarkan tabel diatas diketahui bahwa hasil nilai signifikansi $(0,249$ - 0,979) > 0,05 maka tidak terjadi heteroskedastisitas.

\section{Uji Multikolineritas}

Tabel 12. Hasil Pengujian Multikolineritas Persamaan I

\begin{tabular}{llrc}
\hline & & \multicolumn{2}{c}{ Collinearity Statistics } \\
Model & Tolerance & VIF \\
\hline 1 & (Constant) & & \\
& Karakteristik Informasi Akuntansi & .938 & 1.066 \\
& Desentralisasi & .938 & 1.066 \\
\hline
\end{tabular}

Tabel 12 menunjukkan bahwa semua nilai tolerance $(0,938)>$ dari nilai default yang ditentukan $(0,10)$. Untuk nilai VIF sebesar 1,066 < 10 sehingga semua variabel telah memenuhi persyaratan ambang toleransi dan nilai VIF, artinya pengaruh variabel bebas terhadap variabel terikat tidak terjadi problem multikolinieritas. 
Tabel 13. Hasil Pengujian Multikolineritas Persamaan II

\begin{tabular}{lrr}
\hline & \multicolumn{2}{c}{ Collinearity Statistics } \\
Model & Tolerance & VIF \\
\hline $1 \quad$ (Constant) & & \\
Karakteristik Informasi Akuntansi & .512 & 6.597 \\
Desentralisasi & .730 & 3.034 \\
Partisipasi Anggaran & .922 & 4.499 \\
Interaksi KIA dengan Parisipasi Anggaran & .903 & 6.006 \\
Interaksi Desentralisasi dengan Parisipasi Anggaran & .812 & 1.815 \\
\hline
\end{tabular}

Tabel 13 menunjukkan bahwa semua nilai tolerance $(0,512-0,922)>$ nilai default yang ditentukan sebesar 0,10 . Untuk nilai VIF $(1,815$ - 6,597) < 10 maka semua variabel telah memenuhi persyaratan ambang toleransi dan nilai VIF, artinya bahwa variabel bebas terhadap variabel terikat tidak terjadi problem multikolinieritas.

\section{Uji Regresi Linier}

\section{Tahap 1 Regresi Linier Berganda}

Tahap I merupakan analisis regresi ganda untuk menguji pengaruh karakteristik informasi akuntansi dan desentralisasi terhadap kinerja organisasi. Dalam analysis ini diperoleh standardized coefisien yang menunjukkan koefisien jalurnya

Tabel 14. Hasil Pengujian Regresi Linier Persamaan I

\begin{tabular}{|c|c|c|c|c|c|c|}
\hline & & \multicolumn{2}{|c|}{$\begin{array}{c}\text { Unstandardized } \\
\text { Coefficients }\end{array}$} & \multirow{2}{*}{$\begin{array}{c}\text { Standardized } \\
\text { Coefficients } \\
\text { Beta }\end{array}$} & \multirow[b]{2}{*}{$\mathrm{t}$} & \multirow[b]{2}{*}{ Sig. } \\
\hline \multicolumn{2}{|c|}{ Model } & B & Std. Error & & & \\
\hline \multirow[t]{3}{*}{1} & (Constant) & 2.260 & 1.810 & & 1.248 & .217 \\
\hline & $\begin{array}{l}\text { Karakteristik Informasi } \\
\text { Akuntansi }\end{array}$ & .210 & .029 & .652 & 7.231 & .000 \\
\hline & Desentralisasi & .245 & .113 & .196 & 2.171 & .034 \\
\hline
\end{tabular}

a. Dependent Variable: Kinerja

Organisasi 
Pada tabel 14 dapat diketahui persamaan regresinya, yaitu:

$$
\mathrm{Y}=2,260+0,210 \mathrm{X} 1+0,245 \mathrm{X} 2
$$

Berdasarkan persamaan tersebut dapat diketahui hasil hipotesis :

1. Hasil koefisien regresi karakteristik informasi akuntansi 0,210 dan nilai signifikan sebesar $0,000<0,05$. Berdasarkan hasil pengujian dapat disimpulkan bahwa pengujian tersebut mampu menerima $\mathbf{H}_{1}$, sehingga dugaan adanya pengaruh antara karakteristik informasi akuntansi terhadap kinerja organisasi terbukti atau dapat diterima.

2. Hasil koefisien regresi desentralisasi 0,245 dan nilai signifikan sebesar 0,034 $<0,05$. Berdasarkan hasil pengujian dapat disimpulkan bahwa pengujian tersebut mampu menerima $\mathbf{H}_{2}$, sehingga dugaan adanya pengaruh antara desentralisasi terhadap kinerja organisasi terbukti atau dapat diterima

\section{Tahap II Regresi Linier Berganda Dengan Moderasi}

Pengujian tahap II digunakan untuk mengetahui pengaruh karakteristik informasi akuntansi dan desentralisasi terhadap kinerja organisasi dengan moderasi partisipasi anggaran. Untuk pengujiannya menggunakan Multiple Regression Analysis (MRA) dengan menambahkan perkalian antara variabel karakteristik informasi akuntansi dengan variabel partisipasi anggaran yang menghasilkan variable Moderat 1 dan perkalian antara variabel desentralisasi dengan variabel partisipasi anggaran yang menghasilkan variable Moderat 2.

Tabel 15. Hasil Pengujian Regresi Linier Persamaan II

\begin{tabular}{|c|c|c|c|c|c|c|}
\hline \multirow{3}{*}{\multicolumn{2}{|c|}{ Model }} & \multirow{3}{*}{$\begin{array}{c}\text { Standardized } \\
\text { Coefficients }\end{array}$} & \multirow[b]{3}{*}{$\mathrm{t}$} & \multirow[b]{3}{*}{ Sig. } & \multirow{2}{*}{\multicolumn{2}{|c|}{ Collinearity Statistics }} \\
\hline & & & & & & \\
\hline & & & & & Tolerance & VIF \\
\hline \multirow[t]{6}{*}{1} & (Constant) & & 2.205 & .031 & & \\
\hline & $\begin{array}{l}\text { Karakteristik Informasi } \\
\text { Akuntansi }\end{array}$ & 1.148 & 2.436 & .018 & .512 & 6.597 \\
\hline & Desentralisasi & .694 & 2.383 & .020 & .730 & 3.034 \\
\hline & Partisipasi Anggaran & .172 & .509 & .013 & .922 & 4.499 \\
\hline & $\begin{array}{l}\text { Interaksi KIA dengan } \\
\text { Parisipasi Anggaran }\end{array}$ & 2.320 & 2.619 & .011 & .903 & 6.006 \\
\hline & $\begin{array}{l}\text { Interaksi Desentralisasi } \\
\text { dengan Parisipasi Anggaran }\end{array}$ & .983 & 2.147 & .036 & .812 & 1.815 \\
\hline
\end{tabular}




\begin{tabular}{|c|c|c|c|c|c|c|}
\hline \multirow{2}{*}{\multicolumn{2}{|c|}{ Model }} & \multirow{3}{*}{$\begin{array}{c}\text { Standardized } \\
\text { Coefficients }\end{array}$} & \multirow{3}{*}{$\begin{array}{l}\mathrm{t} \\
2.205\end{array}$} & \multirow{3}{*}{$\begin{array}{l}\text { Sig. } \\
.031\end{array}$} & \multicolumn{2}{|c|}{ Collinearity Statistics } \\
\hline & & & & & \multirow[t]{2}{*}{ Tolerance } & \multirow[t]{2}{*}{ VIF } \\
\hline 1 & (Constant) & & & & & \\
\hline & $\begin{array}{l}\text { Karakteristik Informasi } \\
\text { Akuntansi }\end{array}$ & 1.148 & 2.436 & .018 & .512 & 6.597 \\
\hline & Desentralisasi & .694 & 2.383 & .020 & .730 & 3.034 \\
\hline & Partisipasi Anggaran & .172 & .509 & .013 & .922 & 4.499 \\
\hline & $\begin{array}{l}\text { Interaksi KIA dengan } \\
\text { Parisipasi Anggaran }\end{array}$ & 2.320 & 2.619 & .011 & .903 & 6.006 \\
\hline & $\begin{array}{l}\text { Interaksi Desentralisasi } \\
\text { dengan Parisipasi Anggaran }\end{array}$ & .983 & 2.147 & .036 & .812 & 1.815 \\
\hline
\end{tabular}

Pada tabel 15 dapat diketahui persamaan regresinya, yaitu :

$$
\mathrm{Y}=11,592+0,369 \mathrm{X} 1+0,868 \mathrm{X} 2+0,163 \mathrm{Z}+0,024 \mathrm{X} 1 . \mathrm{Z}+0,050 \mathrm{X} 2 . \mathrm{Z}
$$

Berdasarkan persamaan tersebut dapat diketahui hasil hipotesis :

1. Hasil koefisien regresi interaksi karakteristik informasi akuntansi - partisipasi anggaran diperoleh 0,024 dan nilai signifikansi sebesar $0,011<0,05$. Penjelasan tersebut dapat diartikan bahwa partisipasi anggaran dapat sebagai variabel moderasi dari hubungan antara karakteristik informasi akuntansi terhadap kinerja organisasi, artinya bahwa dengan semakin terbentuk dengan baik partisipasi anggaran maka semakin tinggi pula kinerja organisasi. Oleh karena itu, menerima $\mathbf{H}_{3}$, sehingga dugaan partisipasi anggaran sebagai variabel moderasi pengaruh karakteristik informasi akuntansi terhadap kinerja organisasi terbukti atau dapat diterima.

2. Hasil koefisien regresi desentralisasi - partisipasi anggaran diperoleh 0,050 dan nilai signifikansi sebesar $0,036<0,05$. Penjelasan tersebut dapat diartikan bahwa partisipasi anggaran dapat sebagai variabel moderasi dari hubungan antara desentralisasi terhadap kinerja organisasi, artinya bahwa dengan semakin terbentuk dengan baik partisipasi anggaran maka semakin tinggi pula kinerja organisasi. Oleh karena itu, menerima $\mathbf{H}_{\mathbf{4}}$, sehingga dugaan partisipasi anggaran sebagai variabel moderasi pengaruh desentralisasi terhadap kinerja organisasi terbukti atau dapat diterima 


\section{Hasil Analisis Koefisien Determinasi}

Tabel 16. Hasil Pengujian Koefisien determinasi Persamaan I

\begin{tabular}{lrrrr}
\hline Model & R & R Square & Adjusted R Square & \multicolumn{2}{c}{ Estimate } \\
\hline 1 & $.726^{\mathrm{a}}$ & .527 & .512 & 1.766
\end{tabular}

b. Dependent Variable: Kinerja Organisasi

Berdasarkan tampilan output pada tabel 16 menunjukkan besarnya prosentase variabel kinerja organisasi mampu dijelaskan oleh variabel karakteristik informasi akuntansi dan desentralisasi dengan nilai Adjusted $R$ Square $\left(\mathrm{R}^{2}\right)$ yaitu sebesar 0,512 sedangkan sisanya sebesar $48,8 \%$ dijelaskan oleh variabel lain yang tidak diteliti dalam penelitian ini.

Tabel 17. Hasil Pengujian Koefisien determinasi Persamaan II

\begin{tabular}{lrrrr}
\hline Model & R & R Square & Adjusted R Square & \multicolumn{2}{c}{ Estimate } \\
\hline 1 & $.921^{\mathrm{a}}$ & .849 & .836 & 1.024 \\
\hline b. Dependent Variable: Kinerja Organisasi & &
\end{tabular}

Tabel 17 menunjukkan bahwa besarnya prosentase variabel kinerja organisasi mampu dijelaskan oleh variabel karakteristik informasi akuntansi dan desentralisasi yang diperkuat / dimoderasi oleh variabel partisipasi anggaran dengan nilai Adjusted $R$ Square $\left(\mathrm{R}^{2}\right)$ sebesar 0,836 sedangkan sisanya sebesar $16,4 \%$ dijelaskan oleh variabel lain yang tidak diteliti dalam penelitian ini. 


\section{Hasil Uji Model (uji F)}

Tabel 18 Hasil Pengujian Model (Uji F) Persamaan I

\begin{tabular}{llrrrrr}
\multicolumn{7}{c}{ ANOVA $^{\mathbf{b}}$} \\
\hline Model & & Sum of Squares & df & Mean Square & F & Sig. \\
\hline 1 & Regression & 215.684 & 2 & 107.842 & 34.562 & $.000^{\mathrm{a}}$ \\
& Residual & 193.454 & 62 & 3.120 & & \\
& & 409.138 & & 64 & & \\
& Total & & & & & \\
\end{tabular}

a. Predictors: (Constant), Desentralisasi, Karakteristik Informasi Akuntansi

b. Dependent Variable: Kinerja Organisasi

Tabel 18 adalah hasil pengujian model (Uji F), pengaruh karakteristik informasi akuntansi dan desentralisasi terhadap kinerja organisasi dengan hasil F hitung 34.562 dan tingkat signifikan $0,000<0,05$ sehingga ada pengaruh antara karakteristik informasi akuntansi dan desentralisasi terhadap kinerja organisasi secara bersama-sama dan regresi tersebut layak digunakan dalam penelitian.

Tabel 19. Hasil Pengujian Model (Uji F) Persamaan II

\begin{tabular}{|c|c|c|c|c|c|c|}
\hline \multicolumn{7}{|c|}{ ANOVA $^{\mathbf{b}}$} \\
\hline Model & & Sum of Squares & Df & Mean Square & $\mathrm{F}$ & Sig. \\
\hline \multirow[t]{3}{*}{1} & Regression & 347.226 & 5 & 69.445 & 66.178 & $.000^{\mathrm{a}}$ \\
\hline & Residual & 61.913 & 59 & 1.049 & & \\
\hline & Total & 409.138 & 64 & & & \\
\hline
\end{tabular}

a. Predictors: (Constant), Interaksi Desentralisasi dengan Parisipasi Anggaran, Karakteristik Informasi Akuntansi ,

Partisipasi Anggaran, Desentralisasi, Interaksi KIA dengan Parisipasi Anggaran

b. Dependent Variable: Kinerja Organisasi

Tabel 19 menunjukkan hasil pengujian model (Uji F), pengaruh karakteristik informasi akuntansi dan desentralisasi terhadap kinerja organisasi dengan moderasi partisipasi anggaran dengan hasil $\mathrm{F}$ hitung 66,178 dan tingkat signifikan $0,000<0,05$ sehingga ada pengaruh antara karakteristik informasi akuntansi dan desentralisasi terhadap 
kinerja organisasi dengan moderasi partisipasi anggaran dan regresi tersebut layak digunakan dalam penelitian

\section{Pembahasan}

\section{Pengaruh karakteristik informasi akuntansi terhadap kinerja organisasi}

Hasil koefisien regresi karakteristik informasi akuntansi 0,210 dan nilai signifikan sebesar $0,000<0,05$. Berdasarkan hasil pengujian dapat disimpulkan bahwa pengujian tersebut mampu menerima $\mathbf{H}_{1}$, sehingga dugaan adanya pengaruh antara karakteristik informasi akuntansi terhadap kinerja organisasi terbukti atau dapat diterima. Robbins (2006) menyatakan dalam melaksanakan tugasnya manajer membutuhkan informasi dari berbagai sumber yang sifatnya luas. Karena itu manajer membutuhkan informasi yang memiliki karakteristik informasi akuntansi bersifat relevant, dapat dipercaya (reliable), lengkap (complete), tepat waktu (timely), mudah dipahami(Understandable)serta dapat diuji kebenarannya (verifiable) (Krismiaji, 2010). Dengan karakteristik informasi akuntansi yang semakin baik akan dapat memantu meningkatkan kinerja organisasi. Hasil penelitian ini sama dengan penelitian Penelitian Yudista et al. (2016); Sayyida (2013); Fitriani (2013); Nuraini \& Rosyati (2012), Senduk et al. (2017) dimana hasil penelitian karakteristik informasi akuntansi berpengaruh yang positif dan signifikan terhadap kinerja organisasi. Penelitian lain tentang kinerja organisasi yang hasilnya tidak konsisten dengan penelitian di atas adalah tentng karakteristik informasi akuntansi yang bersifat understandable dan verifiable tidak berpengaruh terhadap kinerja manajerial pada Palang Merah Indonesia (PMI) Provinsi Jawa Tengah (Cahyaningrum \& Suprapti, 2016).

\section{Pengaruh desentralisasi terhadap kinerja organisasi}

Hasil koefisien regresi desentralisasi 0,245 dan nilai signifikan sebesar 0,034<0,05. Berdasarkan hasil pengujian dapat disimpulkan bahwa pengujian tersebut mampu menerima $\mathbf{H}_{2}$, sehingga dugaan adanya pengaruh antara desentralisasi terhadap kinerja organisasiterbukti atau dapat diterima. Desentralisasi dalam bentuk pendistribusian otoritas pada manajemen yang lebih rendah diperlukankarena semakin kompleksnya kondisi administratif, tugas, dan tanggung jawab. Dengan pendelegasian wewenang maka akan membantu meringankan beban manajemen yang lebih tinggi. Menurut Ratnawati \& Setyaningsih (2011), menunjukkan bahwa tingkat desentralisasi yang tinggi merupakan 
bentuk yang tepat untuk menghadapi peningkatan ketidakpastian sehingga menunjang pencapaian kinerja organisasi yang lebih baik. Hasil penelitian ini sama dengan penelitian Afrida (2013); Tarjono \& Nugraha (2015); Meiliza (2018); Senduk et al. (2017) yaitu desentralisasi berpengaruh positif dan signifikan terhadap kinerja organisasi. Namun penelitian tersebut berlawanan dengan Ratnawati \& Setyaningsih (2011) justru menunjukan desentralisasi tidak berpengaruh terhadap kinerja organisasi.

\section{Pengaruh karakteristik informasi akuntansi terhadap kinerja organisasi dengan partisipasi anggaran sebagai variabel moderasi}

Hasil koefisien regresi interaksi karakteristik informasi akuntansi - partisipasi anggaran diperoleh 0,024 dan nilai signifikansi sebesar $0,011<0,05$. Penjelasan tersebut dapat diartikan bahwa partisipasi anggaran dapat sebagai variabel moderasi dari hubungan antara karakteristik informasi akuntansi terhadap kinerja organisasi, artinya bahwa dengan semakin terbentuk dengan baik partisipasi anggaran maka semakin tinggi pula kinerja organisasi. Berdasarkan hasil pengujian maka menerima $\mathbf{H}_{\mathbf{3}}$, sehingga dugaan partisipasi anggaran sebagai variabel moderasi pengaruh karakteristik informasi akuntansi terhadap kinerja organisasi terbukti atau dapat diterima. Dengan karakteristik informasi akuntansi yang baik dan didukung oleh partisipasi anggaran yang baik akan dapat meningkatkan kinerja organisasi.

\section{Pengaruh desentralisasi terhadap kinerja organisasi dengan partisipasi anggaran sebagai variabel moderasi}

Hasil koefisien regresi desentralisasi - partisipasi anggaran diperoleh 0,050 dan nilai signifikansi sebesar $0,036<0,05$. Penjelasan tersebut dapat diartikan bahwa partisipasi anggaran dapat sebagai variabel moderasi dari hubungan antara desentralisasi terhadap kinerja organisasi, artinya semakin terbentuk dengan baik partisipasi anggaran maka semakin tinggi pula kinerja organisasi. Berdasarkan hasil pengujian maka menerima $\mathbf{H}_{\mathbf{4}}$ sehingga dugaan partisipasi anggaran sebagai variabel moderasi pengaruh desentralisasi terhadap kinerja organisasi terbukti atau dapat diterima. Desentralisasi yang merupakan pendelegasian wewenang dan tanggung jawab yang tepat serta didukung oleh partisipasi anggaran yang baik akan dapat meningkatkan kinerja organisasi. Partisipasi tersebut 
menunjukkan adanya interaksi antara para karyawan dengan atasannya, dan karyawan melakukan aktivitas yang diperlukan dari awal penyusunan anggaran, negosiasi, penetapan anggaran akhir dan revisi anggaran yang diperlukan. Sebuah anggaran yang baik adalah anggaran yang dapat memenuhi semua kebutuhan dalam organisasi sehingga dapat mempengaruhi kinerja organisasi.

\section{SIMPULAN DAN REKOMENDASI}

Ada pengaruh antara karakteristik informasi akuntansi dan desentralisasi terhadap kinerja organisasi sehingga hipotesis pertama dan kedua terbukti atau dapat diterima. Partisipasi anggaran mampu memoderasi pengaruh karakteristik informasi akuntansi dan desentralisasi terhadap kinerja organisasi sehingga hipotesis ketiga dan keempat terbukti atau dapat diterima.

Penelitian ini merekomendasikan bahwa organisasi perlu memperhatikan faktor lain yang mempengaruhi kinerja organisasi yang dimungkinkan juga lebih kuat dalam mempengaruhi kinerja organisasi, seperti : tingkat kesejahteraan, lingkungan kerja, program - program pelatihan, peraturan serta kebijakan organisasi dan lain - lain.

Dengan adanya keterbatasan dalam penelitian ini maka untuk peneliti selanjutnya hendaknya dapat menambah sampel penelitian sehingga hasilnya dapat digeneralisasi terkait partisipasi anggaran sebagai variabel moderasi pada pengaruh karakteristik informasi akuntansi dan desentralisasi terhadap kinerja organisasi di perusahaan lain sehingga akan dapat diketahui konsistensi teori yang telah ada untuk dapat dikembangkan dalam rangka meningkatkan kinerja organisasi pada umumnya.

\section{DAFTAR PUSTAKA}

Afrida, Nur. 2013. Pengaruh Desentralisasi dan Sistem Pengendalian Intern Pemerintah Terhadap Kinerja Manajerial SKPD. Jurnal Akuntansi. 1(2) : 1-24. http://ejournal.unp.ac.id/students/index.php/akt/article/view/615

Cahyaningrum, HY dan Suprapti, S. 2016. Pengaruh Karakteristik Informasi Akuntansi Dan Desentralisasi Terhadap Kinerja Manajerial (Studi Pada Palang Merah Indonesia Provinsi Jawa Tengah). Serat Acitya - Jurnal 
Ilmiah

UNTAG

Semarang.

$5(2)$

:83-99

http://jurnal.untagsmg.ac.id/index.php/sa/article/view/475

Dwirandra, AANB. 2007. Pengaruh Interaksi Ketidakpastian Lingkungan, Desentralisasi, Dan Agregat Informasi Akuntansi Manajemen Terhadap $\begin{array}{llll}\text { Kinerja } & \text { Manajerial. } & \text { 2(2) } & \text { : }\end{array}$ Https://Ojs.Unud.Ac.Id/Index.Php/Jiab/Article/View/2556

Eker, Melek. 2007. The Impact Of Budget Participation On Managerial Performance Via Organizational Commitment: A Study On The Top 500 Firms In Turky. Journal Ankara Universitesi SB Fergisi PP. 117-136 https://pdfs.semanticscholar.org/8a20/9d6c700382ed7f7170b4381c63e76 e5ce0ae.pdf

Febrianti, D dan Riharjo, I. B. 2013. Pengaruh Partisipasi Anggaran, Desentralisasi, Komitmen Organisasi dan Ketidakpastian Lingkungan terhadap Kinerja Manajerial Pada Pemerintahan Kota Surabaya. Jurnal Ilmu dan Riset Akuntansi. 1(1) : 108-121.

Fitriani. 2013. Pengaruh Penggunaan Karakteristik Informasi Akuntansi Manajemen Terhadap Kinerja Manajerial. Jurnal Akuntansi. 1(3) : 1 - 30 http://ejournal.unp.ac.id/students/index.php/akt/article/view/694

Hartono, R. dan Anshori, MI. 2019. Peran Kerja Keras Dan Kerja Cerdas Melalui Motivasi Kerja Dalam Meningkatkan Kinerja Karyawan Agent Asuransi (Studi Pada PT. Prudential Life Assurance Surabaya).. Jurnal Kompetensi, 99-112

DOI: https://doi.org/10.21107/kompetensi.v13i2.6828

https://journal.trunojoyo.ac.id/kompetensi/article/view/6828

Ikatan Akuntan Indonesia. 2015. Pernyataan Standar Akuntansi Keuangan

Krismiaji, 2010. Sistem Informasi Akuntansi. Yogyakarta: UPP AMP YKPN.

Mahoney, T.A., T. H. Jerdee \& S.J.Carroll. 1963. Development of Managerial Performance: A Research Approach. Cincinnati: South Western Publishing.

Meiliza. 2018. Pengaruh Desentralisasi, Komitmen Organisasi, Dan Gaya Kepemimpinan Terhadap Kinerja Manajerial Instansi Pemerintahan. 
Jurnal

Akuntansi.

6(3)

$1-17$.

http://ejournal.unp.ac.id/students/index.php/akt/article/view/3790/2450

Muzakki, Wildan, MA dan Safrizal, HBA . 2017. Pengaruh Budaya Organisasi, Motivasi Kerja Dan Organizational Citizenship Behavior Terhadap Kinerja Pegawai Pemerintah Kabupaten Pamekasan. Jurnal Kompetensi. 11(1) : 109-128 DOI: https://doi.org/10.21107/kompetensi.v11i1.3662 https://journal.trunojoyo.ac.id/kompetensi/article/view/3662

Nuraini, A.L. \& Rosyati. 2012. Pengaruh Partisipasi Anggaran Dan Informasi Akuntansi Terhadap Kinerja Manajerial : Komitmen Organisasi, Gaya Kepemimpinan, Ketidakpastian Tugas, Ketidakpastian Lingkungan Dan Strategi Bisnis Sebagai Variabel Moderasi. Proceedings of Conference In Business, Accounting and Management (CBAM) 2012. 1(1) : 99-120 http://jurnal.unissula.ac.id/index.php/cbam/article/view/126

Puryantini, N., Arfati, R. dan Tjahjadi, B. 2017. Pengaruh Knowledge Management Terhadap Kinerja Organisasi Dimediasi Inovasi Di Organisasi Penelitian Pemerintah. Berkala Akuntansi dan Keuangan Indonesia. 2(2) : 21-38. Http://Dx.Doi.Org/10.20473/Baki.V2i2.5325 https://E-Journal.Unair.Ac.Id/Baki/Article/View/5325

Ratnawati, J dan Setyaningsih, D. 2011, Karakteristik Sistem Informasi Akuntansi Manajemen Dan Desentralisasi Serta Pengaruhnya Terhadap Kinerja Organisasi Seminar Nasional Ilmu Ekonomi Terapan Fakultas Ekonomi Unimus 2011.

Hal: 21-32

https://jurnal.unimus.ac.id/index.php/psn12012010/article/view/402

Rivai, Veithzal. 2011. Performance Appraisal, Edisi Kedua Jakarta:Rajawali Pers. Robbins, Stephen, 2006, Perilaku Organisasi, Prentice Hall, edisi kesepuluh Romney, Marshall B. dan Steinbart, (2015), "Sistem Informasi Akuntansi”, Edisi 13, alihbahasa: Kikin Sakinah Nur Safira dan Novita Puspasari, Salemba Empat, Jakarta.

Santoso, EB. Fiernaningsih, N dan Murtiyanto, RK. 2018. Pengaruh Budaya Organisasi Terhadap Kinerja Organisasi. adbis Jurnal Administrasi dan 
Bisnis, 12(1) $\quad$ : $\quad$ http://jadbis.polinema.ac.id/index.php/adbis/article/view/36

Sayyida. 2013. Pengaruh Karakteristik Sistem Informasi Akuntansi Terhadap Kinerja Perusahaan, Jurnal "PERFORMANCE" Bisnis \& Akutansi. III(2) : 17-30 https://www.neliti.com/id/publications/292719

Senduk, J.M , Ilat, V. dan Tirayoh, V. 2017. Pengaruh Desentralisasi, Strategi Bisnis Dan Pemanfaatan Informasi Sistem Akuntansi Manajemen Terhadap Kinerja Manajerial Pada Pt Bank Mandiri Di Manado. Jurnal Riset Akuntansi Going Concern 12(1) : 73-82 https://ejournal.unsrat.ac.id/index.php/gc/article/view/17139

DOI: https://doi.org/10.32400/gc.12.01.17139.2017

Sekaran, Uma. 2006. Metodologi Penelitian Untuk Bisnis, Edisi Keempat. Jakarta: Penerbit Salemba Empat

Setyarini, M.N. \& Susty, AA, 2014. Pengaruh Partisipasi Anggaran Terhadap Kinerja Manajerial Dengan Komitmen Organisasi Sebagai Variabel Intervening Pada Bank Perkreditan Rakyat, Jurnal Modus. 26(1) : 63-76 https://ojs.uajy.ac.id/index.php/modus/article/view/578

DOI: https://doi.org/10.24002/modus.v26i1.578

Sodikin, SS. 2015. Akuntansi Management. Yogyakarta. UPP AMP YKPN

Sukmantari, DAMH. \& Wirasedana, IWP. 2015, Pengaruh Partisipasi Penganggaran Dan Komitmen Organisasi Pada Kinerja Manajerial Dengan Kepuasan Kerja Sebagai Variabel Intervening, E-Jurnal Akuntansi Universitas Udayana. 10(1) : 261-278 https://ojs.unud.ac.id/index.php/Akuntansi/article/view/9983/8133

Susanti, I., Kristiawati, I. dan Sahroni, AB. 2020. Penerapan Sistem Informasi Manajemen Pada Pengambilan Keputusan Manajemen Pt. Jaya Brix Indonesia Di Lamongan. Jurnal Kompetensi, 14(1) : 26-35 DOI: https://doi.org/10.21107/kompetensi.v14i1.7149 https://journal.trunojoyo.ac.id/kompetensi/article/view/7149/4437

Tarjono dan Nugraha, A. 2015. Pengaruh Partisipasi Anggaran Dan Desentralisasi Organisasi Terhadap Kinerja Manajerial Dengan Pengawasan Internal 
Sebagai Variabel Pemoderasi (Studi Analisis Pada Pemerintah Kabupaten Pemalang). Media Ekonomi Dan Manajemen. 30(1) : 85-100 DOI: http://dx.doi.org/10.24856/mem.v30i1.237

http://jurnal.untagsmg.ac.id/index.php/fe/article/view/237

Waluyo, AJ dan Budiarsi, SY. 2016. Sistem Informasi Keuangan Untuk $\begin{array}{lll}\text { Meningkatkan } \quad \text { Kinerja } \quad \text { UMKM. 10(2) } & \text { 103-112 }\end{array}$

Doi: Https://Doi.Org/10.21107/Kompetensi.V10i2.3518

Https://Journal.Trunojoyo.Ac.Id/Kompetensi/Article/View/3518

Widarsono, Agus. 2007. Pengaruh Kualitas Informasi Manajemen Terhadap Kinerja Manajerial (Survey Pada Perusahaan go-Publik di Jawa Barat), Jurnal Akuntansi FE Unsil, 2(2) : 286-300 https://www.academia.edu/11249599

Yudista, O.M., Amilin dan Surtikanti. 2016. Partisipasi Anggaran dan Implementasi Sistem Informasi Akuntnasi terhadap Kinerja Manajerial (Survei Pada Perusahaan Garmen Di Kabupaten Bogor). Jurnal Manajemen. $7(2) \quad: 122 \quad-137$ DOI: http://dx.doi.org/10.32832/jm-uika.v7i2.1109 http://ejournal.uika-bogor.ac.id/index.php/manajemen/article/view/1109. 
Kompetensi, Vol 14, No 2, Oktober 2020 